Editorial

\section{The mind of the terrorist}

\section{Editorial}

In the aftermath of the Paris attacks, we are only beginning to appreciate the magnitude of the problem presented by ISIL. For example, it was learned that the alleged mastermind of the atrocity, Abdel-Hamid Abu Oud, had planned another attack in Paris, which fortunately was disrupted by Parisian law enforcement. Brussels continues to be on highest alert status, with schools closed for more than four days. Most recently, 14 U.S. citizens were murdered in California by a husband and wife team apparently inspired by fundamentalist ideology. Clearly, the Islamic State is succeeding in its goal: to spread fear among its enemies - which is to say, those whose moral, political and/or moral views are different from their own.

Miller $^{1}$ endeavors to understand those who perpetrate acts of terrorism. Important about his thesis is that it includes both psychological and sociological factors. Psychologically, Miller notices intrinsic linkages between ideology and identity, asserting that the former safeguards the latter in those rendered vulnerable by experiences of chronic helplessness, humiliation, and frustrated social aspirations. Evil actors experience themselves as exploited and victimized; they feel trapped by their circumstances, without alternatives or meaningful opportunities for a better life. Anomie and an acute sense of injustice solidify personal and group identity, dehumanizing outsiders (whether individuals, groups or institutions) and transforming them into legitimate targets of hate.

Miller's thesis is controversial for psychological theories that understand motivation as an expression of endogenous factors within the individual and place the greatest weight on those dispositions and inclinations that predispose one to transgression. While it is difficult to imagine perpetration in the absence of projection of hatred and externalization of blame, bigotry and cognitive distortions alone need not devolve necessarily into violence. One can hate those different from oneself without taking any action, either overt or covert, against them.

By contrast, social psychologists endeavor to account for this problem by reference to situational variables alone. For example, Zimbardo ${ }^{2}$ famously claims, "there are no bad apples, only bad barrels" (p.10). In other words, rather than inherently evil or driven by purely pre-programmed traits and inclinations, evildoers are products of the influences around them. What is one to make of the stark contrast between the individual psychology and situational views? Must we choose between character and situation?
Volume 4 Issue 4 - 2015

Ronald C Naso

American Board and Academy of Psychoanalysis, USA

Correspondence: Ronald C Naso,American Board and Academy of Psychoanalysis, 2777 Summer Street, Suite 504B, Stamford, CT 06905, USA, Tel 203-325-366I, Email rcnphd@gmail.com

Received: December 07, 2015 | Published: December 08, 2015

I want to suggest that this is a false dichotomy. Rangell ${ }^{3}$ wrote extensively about the impact of group influences on personality, with particular reference to the corruption of moral values. In brief, it was his view that personality remains open to outside influences throughout the lifespan and, for this reason, may be corrupted by influential leaders as well as by group processes that undermine behavioral restraints and transform moral values. In other words, under the impact of such influences, actions originally perceived as wrong are reinterpreted as desirable and good. For individuals who have been traumatized and experience themselves as disenfranchised, a leader who offers hope and an escape from shame can embolden otherwise moral individuals when his or her message is integrated within an ideological framework that redefines what is good and what is evil. Actions once perceived as wrong now may be experienced as good. To be sure, personal agency rarely is erased entirely, but group identifications and conformity pressures often trump the experience of choice.

\section{Acknowledgments}

None.

\section{Conflicts of interest}

Author declares there are no conflicts of interest.

\section{Funding}

None. 